\title{
The Cinematic "Arab"
}

\author{
By David H. Anthony \\ Spring 2006 Issue of KINEMA
}

\section{THE CINEMATIC "ARAB": FROM THE LONG SHIPS TO HIDALGO}

IMAGES of "Arabs" have been perennial staples of both Hollywood feature films and US television. The degree to which these are stereotypical has been examined in studies by several critics. In spite of their admonitions, however, they remain fixtures of America's dream factory. The recent film Hidalgo reveals the reproduction of these tried and not so true representations, but also seeks to address some of the criticisms and to make redress for transgressions visited upon the two principal groups depicted within it, "Arabs" and Native American Indians. In the course of doing so, it takes on North American "racial" formation, historical relations between the New and Old Worlds and British imperialism.

Finally, Hidalgo is a curiously complex tricolour tapestry of racial binaries, the antinomies of "White" vs "Red," "Black" vs "White," "White" vs "Arab" and "Red" vs "Arab." If it may be argued that several of these oppositions have novel elements, it is also evident that they bear comparison to earlier scenes in both the recent and distant celluloid past. Embedded within this set of representations is the understudied signifier of "Afro-Arab."

That racial diversity exists and has existed within the Arab world has long been a subject of Arabists, Islamicists and Africanists. Such scholars as Bernard Lewis and John Ralph Willis have addressed it directly, principally in terms of links between "race" and slavery. Until their compulsory introduction into Kuwait and Saudi Arabia with the onset of the Persian Gulf and Iraq wars, however, most Americans had not taken note of this. Since the emergence of al-Qaeda and the spate of bombings directed at US installations and interests inside the Middle East, Eastern Africa and North America, culminating in the September $11^{\text {th }}$ attacks, the largely unspoken factor of "race" has formed an undercurrent in the discourse on "Arab," "Islamic" and "fundamentalism-inspired" terrorism which has provoked much heated debate within a terrified American populace and the resort to military expedients to combat a perceived "Islamic threat."

One ideological battleground within which this struggle has been waged has been the arena of the moving pictorial image, most notably in feature and documentary film, and to a lesser but significant extent in videotape and television. The recent release of the critically acclaimed action film Hidalgo "based upon a true story" has been an example of this concern. While it contains a familiar assortment of "Hollywood Arab" villains and a few "noble savage" heroes (and one ingénue heroine) it does appear to make larger moral points including a plea for mutual understanding and tolerance between the Muslim and Christian worlds. In doing so it offers verbal and visual comments on Black slavery, Red expropriation and White supremacy, within a context establishing the cinematic specificity of "Arabness."

If Hidalgo shares some characteristics of the 2003 sleeper The Last Samurai (framed by closure of the American West; employed in farcical Wild West show parody; disaffected, alcoholic and marginalized warweary frontier warrior unwillingly forced into an oversea transcultural expedition), unlike the former Hidalgo does not offer much that is appealing to its Mixed-Race protagonist, Frank T. Hopkins, about the Arab and Muslim worlds into which he is coercively introduced. It is in many ways yet another instance of external encroachment upon and interference in the life of an outsider wishing to be left alone.

He is like Hombre, the heroic anti-hero who brings an embittered dignity to the alienated outcast position of "half breed," a potent, spiritually pernicious Hollywood construction. Frank T. Hopkins is like most "Hollywood half breeds" a tortured individual. In his case, not only is he a typical "child of two worlds" unable to fully fit in either of them, he has also witnessed the aftermath of the horrifying massacre of Wounded Knee Creek in 1890.

After being introduced as "Blue Child" whose Native mother taught him her language, Hopkins spends the beginning of the film striving to escape his past, fleeing himself and his demons, symbolized by images of 
the genocide practised by White Power in its desire to rid the West, the frontier and American society of its first inhabitants, Native Peoples.

Frank's partner "Hidalgo" is a Mustang he races to scores of local and regional victories. When seen performing in Buffalo Bill Cody's Wild West Show by a representative of a wealth Arab sheikh whose horse al-Hattal is reputed to be the best in the world, Hopkins and Hidalgo are compelled to accept his challenge to compete in a deadly desert contest.

The transition from the red dirt of the circus-like settings of Cody's Wild West show to a steamship transporting him from New York to the Sahara's steamy sands could not be more stark. But this is only the beginning of what Hopkins and Hidalgo will face. Much of this will be presented to him with vivid power, such as his first witness of slave coffles as the Sheikh (played by veteran Egyptian actor Omar Sharif) asks, "have you never seen a slave market?" The procession is of black bondsmen, including children, one of whom will later be shown on the auction block. The distinction between them, their appearance, both in terms of colour and their dishevelled attire clearly makes the point of privilege, in terms of "race" and class. Yet, the participants in the great race, the balance of whom are "Arab," are seen in a variety of hues. While there is no shortage of dark brown, visually African-descended servants, many of the horsemen run the gamut of browns, from tan to sepia, some readily recognizable as what we would today identify as African-Americans.

Africans and African-Americans are abundantly evident in Hidalgo, as actors and even in the syncretic, multicultural musical score by composer and flutist James Newton Howard.

African-Americans are hardly newcomers to films set in Middle Eastern "Arab" locales. As long ago as the premier edition of Cecil B. de Mille's The Ten Commandments, Negro Americans (as they would have been known then) are easily seen at different points in the crowd, from the building of the pyramids onward. They reappear with each of de Mille's two successive remakes, climaxing in the sound and colour epic starring Charlton Heston. For the most part, however, these actors are mute, silent sphinx-like landscape presences.

When dark-skinned, "Arab" delineators are called upon to speak in dramatic roles, they are invariably played by White actors in blackface (not infrequently British) such as Rex Harrison's Saracen Saladin (Salah alDin) or Sir Lawrence Olivier's Othello and Mahdi (Abdullah Muhammad), antagonist of Charlton Heston's George "Chinese" Gordon in Khartoum. Humour, however, leaves room for other possibilities, as witness Rex Ingram whose outsized, devilishly jovial genie (jinn) in Sinbad offers comic relief par excellence. The genie of the lamp is, of course, a slave of whoever owns and rubs it, "whose wish is his command." This, an extension of the roles Black folk played in American life and on screen, is hardly a stretch. It is thus not surprising to see Black servile attendants in the quarters of Cleopatra. What was jarring for American audiences was when Bahamas-born Sidney Poitier, then known primarily as a pioneer in post World War Two African-American film, co-starred in the eccentric East Meets West horse opera, The Long Ships.

The Long Ships is a now largely forgotten tale of a highly improbable encounter between a Viking sea captain played by Richard Widmark and a fierce Moorish lord (Poitier) who struggle over the possession of a gilded, somehow strangely occluded bell. In the course of their combat Poitier's character shows his phenomenal personal power by presiding over selfless subjects who will cheerfully sacrifice themselves by "riding the 'Mare of Steel'," an equine contraption with a huge scimitar-shaped blade that slices them in half.

Poitier sports a long dark straight wig that drew comment in some reviews of the film. He also had a curious conjugal relationship with a Caucasian (read Circassian) femme fatale.

The juxtaposition of the "Blackamoor" and the Blonde Viking was far more interesting than many audience members may have realized. Taking place within the context of Poitier's rise as a Civil Rights era cinematic icon, it also suggested something about race in Muslim lands well before the advent of the era of Muhammad Ali, who became not only US and world heavyweight champion, but a standard bearer for global Islam. As odd as Poitier might have looked and felt in this part (his first autobiography This Life claims he hated it), viewed from the standpoint of depictions of both Black actors and "Arabs," while retaining elements of the "noble savage" stereotype it was truly unique.

Poitier's Moor, though sharing some of the stereotypical characteristics of noble savage subjects as well as those of Hollywood Arabs (impetuousness, emotionalism, violence) is fearless, prepared to die, confident to 
the point of arrogance, self-possessed and leonine.

Moreover, he is a person of obvious high social standing and is revered by his followers. His rule is not questioned even at its most arbitrary, despotic, high-handed or tyrannical. His troops are highly disciplined, completely devoted and look ready for any eventuality. He is also single-minded about possessing the bell at all costs and unwilling to listen to anyone who resists or questions his right to do so. He is in many ways the antithesis of the spirit of compromise, conciliation, patient resignation and nonviolence of the Civil Rights era. If anything he is more in sync with Malcolm X, Black Nationalism and Black Power. Contemporary AfricanAmerican cultural nationalists recognized this at the time. Such a character appearing in a similar position today could risk invidious comparisons domestically to Louis Farrakhan and internationally to Osama bin Laden and al-Qaeda.

Not until Laurence Fishburne took the movie role of Othello did another "noble" African-descended thespian appear as a Moor in a lead role in a major motion picture. James Earl Jones made numerous appearances as the Moor of Venice on stage, both nationally and internationally, but Fishburne's performance was unusual in its overt embrace of Africa.

In the television mini-series Sadat, Louis Gossett Jr. portrayed the brown-skinned former Egyptian head of state. While he may have exaggerated the mannerisms of the martyred Nubian, Gossett did seek to portray the statesman in an earnest, principled manner. This inspired portrait of the man and the path-breaking vehicle itself, have also been forgotten.

Even though Hidalgo retains some retrograde elements, casting represents something of a triumph. In the now aged Omar Sharif it boasts perhaps the most seasoned survivor of twentieth century Arab cinema, clearly still in possession of his considerable gifts. It is not difficult for him to show dignity as the Sheikh of Sheikhs. It is a long way from his debut as the impulsive, headstrong Faisal in David Lean's Lawrence of Arabia, where he shared the screen not only with Peter O'Toole as the eponymous adventurer and author of Seven Pillars of Wisdom, Thomas Edward Lawrence, but with character actor Anthony Quinn, whose family tree links him to Ireland and Mexico, but not to 'Arabiyya (hence the need for a hawklike faux proboscis) and a cast of thousands of authentic Arab extras.

Hidalgo is also distinguished by its use of the Arabic language, clearly articulated even when repeated phonetically, as was the case in its use of select spoken Siouan sequences.

Though this in and of itself may not be sufficient to permit the film to rise above clichés, it does add a measure of veracity to at least some of the verbal bantering between players.

\section{White vs Red}

The poignant murder of the Native people cornered and assassinated at Wounded Knee Creek reminds us that they and their mustangs are an endangered species, in the eyes of the Whites who seek to remove them from the face of the earth through their gun sights.

\section{Black vs White}

Slavery is the point of entry in the opposition between Black and White, directly in the memory of American slavery and indirectly in the "White" slaveholding Arab traders. The other dimension of Black and White is represented by the high number of African- Americans and Africans involved at every level of the production of Hidalgo. These range from the incomparably beautiful Zuleikha Robinson, who plays Jazira, daughter of the Sheikh, to Peter Mensah, to the aforementioned composer James Newton Howard.

\section{White vs Arab}

Explicitly the major conflict between Whites and Arabs unfolds in the relationship of the English Lady, who represents imperial and soon-to-be colonial Britain. She has no doubt of her superiority, racially, morally, financially, politically and culturally. Yet implicitly there is another conflict pitting America against 'Arabiyya racially as well as culturally. While mixed, Hopkins' cowboy status makes him represent a "White" American "race." That is revealed in the Sheikh's fondness for tales of the Wild West, humanizing him in the era of the Iraq war. Since Hopkins the cowboy has direct knowledge of Buffalo Bill Cody the Sheikh sees Frank as an extension of the romance of the Wild West he created.

\section{Red vs Arab}


Hopkins' "red" ancestry is discovered by the English woman who is striving to beat al-Hattal. She and her spouse (played in a cameo by the now mature Malcolm McDowell) ruminate upon the meaning of the term "mixed", as applied first to horseflesh in the case of mustangs like Hidalgo, and then by extension to human beings with Hopkins in mind. This mestizaje, this despised and ostensibly rotten fruit of miscegenation is contrasted with the purity of the bloodlines of the thoroughbred al-Hattal and his sundry Arab foes. By extension we can consider America a kind of mongrel continent, built upon more mixtures of breeds of animals, humans and plants than any other in recorded history. And yet a casual glance at the faces of the men, women and children in the deserts and oases of 'Arabiyya will remind us that North Americans are not the only mixed "race."

Perhaps this is why the horse people of the dunes place so much emphasis on breeding their equestrian wards, for theirs may be the only genealogies that they can truly control.

\section{Arab vs Black}

One of the most complex questions in Hidalgo and indeed within the Arab World itself concerns the relationship between "Arabs" as social types and Black or African subjects. The complexity derives from the fact that Africans have played a variety of roles in Arab society, although African slavery has been a consistent feature of this relationship down through to the present day. It has been the source of friction in present-day Sudan, Mali, Senegal, Niger, Mauritania and most of the other Afro-Arab borderlands (Libya, Chad). Black-skinned people depicted in this film reflect this range of roles, from the slaves in the earliest sequences of Hopkins' introduction to the world of the Sheikh and al-Hattal, to the dramatic character of the bodyguard of the Sheikh who looks like a palace eunuch.

Yet racially, these relationships go unspoken. There is abuse and oppression, but it is not always apparent that this is simply or partly racial, as it seems indicative of class as well. The fact remains, however, that we are presented with slaves who are all dark-skinned of African Descent, while brown and light brown workers appear in some kind of hierarchy that serves to obscure their status. Because anyone from anywhere can be a mother to an Arab male, including a concubine or a slave, from Ethiopia, Somalia, Sudan or the Sahel, "race" and class are not always easily connected. Skin color is only one variable in the retinue of characteristics that help locate the position of particular characters in the film.

At the same time, aural and visual references to slave vending are too visceral for some Americans to ignore, chiefly Black Americans, but may give many others pause as well. Whether or not it is mentioned in the film this shall be evident to most viewers, however briefly, and it might remain on their minds well beyond those sequences in which slaves appear on screen. Almost invariably they could cause audiences to ask themselves, who are these people? Where do they come from? What is their connection to the set-up we are viewing? The film will not answer these questions. It allows us to see them only as Hopkins sees them, and he is revealing very little other than the fact that he does indeed notice them. He does not speak about them. Only once does he retaliate against an act of abuse levelled at one of them, an unnamed slave child who he tells to fetch water, who is in turn mistreated by Hopkins' Arab servant, the offending goat-herd whose punishment is to attend to him. He is not in any other sense either a critic or crusader against slavery or servile maltreatment. That slavery might have distressed him we are left to infer, for Hopkins will not give Hidalgo's viewers any firm indication that this may have been so.

But many people of African descent may find themselves looking for those "sale items," the human chattel, wondering about their fate, their destination and their very life spans. In juxtaposing images of North American and Arab slavery the film implicitly, perhaps explicitly suggests a parallelism in the two situations where black slavery is concerned. If unflattering to White Americans this will not endear US audiences to Arabs either.

That "Hidalgo" has been released in the midst of yet another Persian Gulf war may make it both timely and problematic as western "crusaders" strive to extricate themselves from the quicksand of the desert. 


\section{Author Information}

David H. ANTHONY is Associate Professor at the History Department, University of California, Santa Cruz. His research concentrates on 'The Americas and Africa.' Recently, he published Max Yergan: Race Man, Internationalist, Cold Warrior (NYU Press, 2006). 